\title{
Growth Response of Seedlings of Four Robusta Coffee (Coffea canephora Pierre. Ex. A. Froehner) Clones to Drought Stress
}

\author{
Novie Pranata Erdiansyah ${ }^{1 *}$, Ade Wachjar ${ }^{2)}$, Eko Sulistyono ${ }^{2)}$, and Supijatno ${ }^{2)}$ \\ ${ }^{1)}$ Indonesian Coffee and Cocoa Research Institute, Jl. PB. Sudirman 90, Jember Indonesia \\ ${ }^{2)}$ Department of Agronomy and Horticulture, IPB University, Dramaga, Bogor, Indonesia \\ Corresponding Author : wachjarade@yahoo.com \\ Received: 21 January 2019 / Accepted: 15 March 2019
}

\begin{abstract}
Drought is one of the limiting factors for the growth and yield of coffee plants. Drought due to long dry season has caused many losses for coffee plantations. This study aimed to evaluate the response of four Robusta coffee clones to drought stress at seedling stage and determine the best clone with high tolerance to drought. The study was conducted in Indonesian Coffee and Cocoa Reseach Institute (ICCRI) Jember, East Java in November 2018-Mei 2019. The experimental design used a Randomized Block Design (RCBD) with two factors. The first factor has consisted of five levels drought through providing volume watering based coefficient and evaporation value of free water surface (Eo), namely: 0.5 Eo; 1.0 Eo; 1.5 Eo; 2.0 Eo; 2.5 Eo (control). The second factor has consisted of four Robusta coffee clones, namely: BP 409 (drought tolerant clone); BP 308; BP 939 and BP 358 (vulnerable to drought stres). The result showed that reduction in the volume of watering from 2.5 Eo until 0.5 Eo causes drought, reduce coffee growth linearly. Clone BP 409 and BP 939 had better tolerance of drought stress compared with BP 308 and BP 358. The anatomical adaptation of leaves of BP 409 to drought stress was by thickening of wax layer and palisade tissue. BP 939 thickened its leaves due to drought stress as a mechanism of adaptation to such condition.
\end{abstract}

Keywords: Coffea, clonal, drought, mekanism

\section{INTRODUCTION}

The long drought that once occurred in Indonesia had caused losses for coffee plantations including decreased production and death of young plants in former PT. Perkebunan XVIII and XXIII in 1982. The decline in production that occurred in PTP XXIII due to long drought reached 34-68\% with death rates ranged 5.4-7.5\%. In 1991 in several coffee plantations in East Java a long dry season also occurred. The impact of the dry season in 1991 was quite heavy as revealed from a great number of coffee plants' canopies dried up, especially those of Robusta coffee in lowlands. Before 1982, the occurrence of long dry season recurred every 10 years and since 1982-1992 the cycle had become merely 5 years. However, in the last few years, the season becomes more unpredictable (Abdoellah, 1997).

According to Salisbury \& Ross (1995), drought stress that occurs on plants can be interpreted as all changes in unfavorable environmental conditions that might reduce or destruct the growth or development of plants. Symptoms of damage to Robusta coffee due to drought stress in the field can be observed from the wilting and yellowing of leaves in the early stages and drying of leaves and branches (dieback) if drought 
stress continues. As a result, the young flowers and fruits found in the branches also become dry that the production in the following years will be greatly reduced. If the drought is very heavy, the plants can die (Nur, 1992). According to Dominghetti et al. (2016), the groundwater field capacity below $74.6 \%$ can be dangerous for coffee seedlings which are resulted from somatic embryogenesis and cuttings. Anticipation to reduce the impact of drought stress has been carried out by coffee growers. The best solution is by watering or irrigation (Abdoellah, 1997). Irrigation is easy to do in Indonesia but requires high costs, especially for land with less water. Another easy and efficient way to deal with the drought in Indonesia is by using tolerant clones to drought stress.

King' oro et al. (2014) investigated the tolerance level of one type of Robusta coffee seedlings and nine types of Arabica coffee seedlings against drought. The results showed that there was a decrease in the number of leaves, number of internodes, plant height, percent of root biomass and crowns due to drought stress for all genotypes. It was also explained that the type of Arabica coffee seedlings Tall had better resistance to drought stress.

The results of Chemura et al.'s (2014) research showed that before the drought period the coffee plants produced the same biomass, but after the period of drought for 21 days there was a difference in biomass between the coffee clones tested. Furthermore, it was stated that root biomass was an important factor in determining coffee varieties which are tolerant of drought stress. Deeper root systems of tolerant clones make it possible to get greater access to water at the bottom and to maintain more favorable internal water status than drought-sensitive clones (Pinheiro et al., 2005; Achar et al., 2011)
Another investigation conducted by Tesfaye et al. (2015) reported that the anatomy of Robusta coffee leaf adapted to drought stress conditions. The variables of leaf extension rate and specific area size (approach to calculating leaf thickness) are important indicators in the selection of tolerant genotypes to drought stress. According to Farooq et al. (2009), smaller leaf area when plants are experiencing drought stress is a mechanism to reduce water loss to the environment from plant tissue. Similar to Robusta coffee, Melo et al. (2014) explain that modification of the upper epidermis and palisade tissue thickness are important variables for selection of Arabica coffee plants which are tolerant to drought stress. Batista et al. (2010) add that Arabica Bourbon Amarelo and Catimor have a good tolerance to drought stress due to their thicker cuticle and palisade tissue, larger bundle sheets and higher stomatal density. This causes the varieties to be more efficient in minimizing the rate of transpiration and increasing photosynthetic activity in drought stress conditions.

The agronomic/morphological approach is carried out to correlate the tolerance level of Robusta coffee to drought stress because of its easiness to apply (Anim-Kwampong \& Adomako, 2010; Anim-Kwampong et al., 2011). Silva et al. (2013) argue that combining morphological and physiological characteristics is useful for evaluating the success of the performance of coffee clones in response to drought stress at the nursery stage. The purpose of this research is to find out the growth response of Robusta coffee seedlings to drought stress at the seedling phase as well as to obtain Robusta coffee clones that have tolerance to drought stress at the seedling phase and to know their tolerance mechanism. 


\section{MATERIALS AND METHODS}

The research was carried out at the Kaliwining Experiment Farm, the Indonesian Coffee and Cocoa Research Institute in Nogosari Village, Jenggawah District, Jember Regency, East Java Province. The research was conducted from November 2017 to May 2018. The materials were Robusta coffee seedlings from four-month-old cuttings. The clones used were BP 409 (drought-tolerant clone), BP 308, BP 939, and BP358 (clones prone to drought stress).

The experimental design used was a randomized block design with two factors. The first factor consisted of five levels of drought through providing volume watering based on the treatment coefficient and the evaporation value of the free water surface (Eo), namely: 0.5 Eo; 1.0 Eo; 1.5 Eo; 2.0 Eo; 2.5 Eo (control). The second factor consisted of 4 types of Robusta coffee clones, namely: BP 308; BP 358; BP 409; BP 939. There were total 20 treatment combinations were obtained, and each treatment combination was repeated 3 times. Thus, 60 experimental units were obtained. Each unit of experiment had 5 plants, hence the total number of plants were 300 plants. If the results of variance showed an effect on the $\mathrm{F}$ test with a level of $\alpha 0.05$, then it was followed by the Duncan multiple range test (DMRT) and orthogonal polynomial test at the level of 5\%. Besides, the calculations were performed using STAR 2.0.1 software.

The seeds were from cuttings of coffee plants consisting of four clones according to the treatment. These planting materials were taken from a 15-year-old production plantation located at the Kaliwining Experiment Farm in the Indonesian Coffee and Cocoa Research Institute. The method of propagating coffee plants was by using cuttings based on the technical guidelines for coffee plantations published by the Indonesian Coffee and Cocoa Research Center (Puslitkoka, 2006). Seedling preparation was carried out for 4 months with the detail as follows: 3 months for growing roots in beds and 1 month for seed adaptation in polybags. Meanwhile, the planting media were soils that had been cleaned from gravels and rocks or other materials by sieving, then the soils were airdried until dry. After well-dried, the soils were put into the polybags with the same weight. The diameter and the height of the polybags after being filled with the planting media were measured in $\mathrm{cm}$ as data for determining the watering volume.

Further, the drought treatment was carried out by providing irrigation every 2 days with the volume according to the treatment. The irrigation volume was calculated based on the formula VI = E x A x Ko, where VI = volume of irrigation $\left(\mathrm{cm}^{3}\right), \mathrm{E}=$ pan evaporation $(\mathrm{cm}), \mathrm{A}=$ pot surface area $\left(\mathrm{cm}^{2}\right)$ and Ko $=$ treatment coefficient $(0.5,1.0,1.5,2.0,2.5)$. The pan evaporation was measured before irrigation. This evaporation value was gained based on the water balance, namely $\mathrm{P}=\mathrm{E}$ $+\triangle \mathrm{H}$. $\mathrm{P}, \mathrm{E}$, and $\triangle \mathrm{H}$ are respectively rainfall $(\mathrm{mm})$, pan evaporation $(\mathrm{mm})$ and changes in the height of the water in the pan ( $\mathrm{mm})$. The rainfall was equal to zero because this research was carried out in plastic houses (Sulistyono \& Juliana, 2014; Sulisyono \& Rianti, 2016). The drought period for coffee seedlings was for three months or 90 days.

Observations were made on three sample plants per experiment unit, while the other two sample plants were for destructive observation. Parameter of plant morphology (plant height, stem diameter, number of leaf pairs) were observed every 2 weeks during the drought period whereas the parameters of the biomass and seedling root (wet weight, total dry weight, root length, root volume) and leaf anatomical parameters (stomatal density, leaf thickness, cuticle and palisade tissue thickness) were observed at the end of a drought period. 
Goldesworthy \& Fisher (1996) group palant tolerant to abiotic stress based on Stress sensitivity index (SSI) into three group, that is $\leq 0.5$ toleran, $0.5-1.0$ moderate, and $\geq 1.0$ susceptible. The Stress Sensitivity Index was measured using the formula SSI $=(1-y / y p) /(1 x / x p)$, where $y=$ the growth value of coffee seedlings experiencing drought stress, $y \mathrm{p}=$ the growth value of coffee seedlings which are not affected by stress drought, $x=$ the mean value of coffee seedling growth in the drought treatment group experiencing drought stress, $x p=$ the mean value of coffee seedling growth in the drought treatment group that does not experience drought stress. The variables used to measure the stress sensitivity index in this research is the plant height variable because this is one of the indicators used for seeds ready to be distributed

\section{RESULTS AND DISCUSSION}

\section{Seedling Growth}

The results showed that drought significantly affected the growth of Robusta coffee seedlings. Reduction in the volume of watering from 2.5 Eo until 0.5 Eo causes drought, reduce coffee growth linearly. The growth response pattern from the height of Robusta coffee seedlings to the drought provision started to be seen in week 4 . The response pattern formed followed the linear regressions. Similarly, it also occurred to the variables of stem diameter and number of leaf pairs. However, in the number of leaf pairs variable, the response pattern formed began to show in the tenth week after first $d$ rought treatment (Table 1)

Table 1. Growth of Robusta coffee seedlings in several drought levels at 12 weeks after first treatment

\begin{tabular}{|c|c|c|c|c|c|c|c|}
\hline \multirow{2}{*}{ Drought level (Eo) } & \multicolumn{7}{|c|}{ Age of seedling (week after first drought treatmen) } \\
\hline & 0 & 2 & 4 & 6 & 8 & 10 & 12 \\
\hline & \multicolumn{7}{|c|}{----------- Seedlings height $(\mathrm{cm})$----------- } \\
\hline 0.5 & 12.36 & $13.18 \mathrm{~b}$ & $13.94 \mathrm{c}$ & $14.61 \mathrm{c}$ & $15.16 \mathrm{c}$ & $15.59 \mathrm{~d}$ & $17.44 \mathrm{c}$ \\
\hline 1.0 & 12.94 & $14.04 \mathrm{~b}$ & $15.19 \mathrm{~b} \mathrm{c}$ & $16.47 \mathrm{~b}$ & $17.65 \mathrm{~b}$ & $18.47 \mathrm{c}$ & $20.69 \mathrm{~b}$ \\
\hline 1.5 & 12.20 & $13.52 \mathrm{ab}$ & $14.96 \mathrm{~b} \mathrm{c}$ & $16.92 \mathrm{~b}$ & $19.19 \mathrm{~b}$ & $20.36 \mathrm{~b}$ & $22.22 \mathrm{~b}$ \\
\hline 2.0 & 13.62 & $15.49 \mathrm{a}$ & $16.94 \mathrm{a}$ & $19.42 \mathrm{a}$ & $22.26 \mathrm{a}$ & $23.57 \mathrm{a}$ & $26.37 \mathrm{a}$ \\
\hline 2.5 (control) & 13.22 & $14.78 \mathrm{ab}$ & $16.54 \mathrm{a} \mathrm{b}$ & $19.90 \mathrm{a}$ & $22.87 \mathrm{a}$ & $24.18 \mathrm{a}$ & $26.97 \mathrm{a}$ \\
\hline F test & $\mathrm{ns}$ & $*$ & $* *$ & $* *$ & $* *$ & $* *$ & $* *$ \\
\hline \multirow[t]{2}{*}{ Response } & $\mathrm{ns}$ & ns & $\mathrm{L}^{*}$ & $\mathrm{~L}^{* *}$ & $\mathrm{~L}^{* *}$ & $\mathrm{~L}^{* *}$ & $\mathrm{~L}^{* *}$ \\
\hline & \multicolumn{7}{|c|}{----------- Stem diameter (mm) ----------- } \\
\hline 0.5 & 2.38 & 2.90 & $3.10 \mathrm{~b}$ & $3.12 \mathrm{c}$ & $3.16 \mathrm{c}$ & $3.25 \mathrm{c}$ & $3.47 \mathrm{c}$ \\
\hline 1.0 & 2.53 & 2.96 & $3.28 \mathrm{ab}$ & $3.38 \mathrm{~b}$ & $3.43 \mathrm{~b}$ & $3.52 \mathrm{~b}$ & $3.76 \mathrm{~b}$ \\
\hline 1.5 & 2.33 & 2.89 & $3.31 \mathrm{a}$ & $3.43 \mathrm{~b}$ & $3.49 \mathrm{~b}$ & $3.59 \mathrm{~b}$ & $3.87 \mathrm{ab}$ \\
\hline 2.0 & 2.45 & 2.93 & $3.35 \mathrm{a}$ & $3.51 \mathrm{ab}$ & $3.60 \mathrm{ab}$ & $3.69 \mathrm{ab}$ & $3.98 \mathrm{ab}$ \\
\hline 2.5 (control) & 2.47 & 3.01 & $3.47 \mathrm{a}$ & $3.67 \mathrm{a}$ & $3.75 \mathrm{a}$ & $3.85 \mathrm{a}$ & $4.08 \mathrm{a}$ \\
\hline F test & $\mathrm{ns}$ & $\mathrm{ns}$ & $* *$ & $* *$ & $* *$ & $* *$ & $* *$ \\
\hline \multirow[t]{2}{*}{ Response } & $\mathrm{ns}$ & $\mathrm{ns}$ & $\mathrm{L}^{* *}$ & $\mathrm{~L} * *$ & $\mathrm{~L}^{* *}$ & $\mathrm{~L}^{* *}$ & $\mathrm{~L}^{* *}$ \\
\hline & \multicolumn{7}{|c|}{-------- Number of leaf pairs ---'--'--- } \\
\hline 0.5 & 4.05 & 4.66 & 5.38 & $5.63 \mathrm{ab}$ & $5.60 \mathrm{bc}$ & $5.81 \mathrm{~b}$ & $6.44 \mathrm{~b}$ \\
\hline 1.0 & 4.10 & 5.00 & 5.59 & $5.95 \mathrm{ab}$ & $5.83 \mathrm{abc}$ & $6.33 \mathrm{ab}$ & $6.87 \mathrm{ab}$ \\
\hline 1.5 & 3.83 & 4.69 & 5.38 & $5.50 \mathrm{~b}$ & $5.56 \mathrm{c}$ & $6.14 \mathrm{ab}$ & $6.51 \mathrm{~b}$ \\
\hline 2.0 & 4.25 & 4.95 & 5.64 & $6.06 \mathrm{a}$ & $6.12 \mathrm{a}$ & $6.73 \mathrm{a}$ & $7.23 \mathrm{a}$ \\
\hline 2.5 (control) & 4.10 & 5.03 & 5.51 & $6.00 \mathrm{a}$ & $6.03 \mathrm{ab}$ & $6.67 \mathrm{a}$ & $7.14 \mathrm{a}$ \\
\hline F test & $\mathrm{ns}$ & $\mathrm{ns}$ & ns & $*$ & $*$ & $* *$ & $* *$ \\
\hline Response & $\mathrm{ns}$ & ns & ns & ns & ns & $\mathrm{L}^{* *}$ & $\mathrm{~L}^{*}$ \\
\hline
\end{tabular}


Reduction in the volume of watering from 2.5 Eo until 0.5 Eo causes drought, reduce coffee growth linearly. The response pattern of plant height due to drought treatment in week 4 after treatment follows the equation $\mathrm{y}=1.5732 \mathrm{x}+13.245$ while the pattern started from week 12 after treatment follows the equation $y=5.1394 x+15.125$. The results of these equations showed that in the $12^{\text {th }}$ week the effect of drought was stronger on the plant height variable. Stem diameter also showed the same growth pattern as plant height. The regression equation of stem diameter formed in week 4 after treatment is $\mathrm{y}=0.16 \mathrm{x}+3.06$, and that in week 12 after treatment is $\mathrm{y}=0.2911 \mathrm{x}+3.3931$. Furthermore, the regression equation formed for the variable of number of leaf pairs is $y=0.424 x+6.244$. The regression equations show the response patterns of drought treatment to the growth variables (plant height, diameter, and number of leaf pairs). These equations can be used to predict the growth of Robusta coffee cuttings when given watering volume starting at 0.5 Eo2.5 Eo from 0 up to 12 week after first drought treatment. The results of this research are in line with that of Mohammed et al. (2018) which state that drought stress for 28 days (4 weeks) causes a significant difference in the growth of Robusta coffee plants, and this could be seen more clearly in the variable of total dry weight of plants. Similar findings are also found in Arabica coffee seedlings, namely 21 days of drought stress causes significant differences in plant biomass accumulation (Chemura et al., 2014).

Reduction in the volume of watering from 2.5 Eo until 0.5 Eo causes drought, reduce coffee growth linearly. According to Gardner et al. (1985), the role of water for plant growth serves as the main constituent of plant tissues, solvent and medium for cell metabolic reactions, medium for transporting solutes, medium that provides turgor to plant cells, and as a raw material for photosynthesis, hydrolysis processes and other chemical reactions and evaporation water to cool the surface of the plant. When plants are in a lacking water condition, the growth process will be hampered. Drought stress affects the assimilation of plants by changing metabolic activity, inhibiting a series of metabolism or enzyme reactions, and changing the balance between parts of the metabolic system. This causes plants to reduce net photosynthesis because of increased stomatal diffusion. In addition, drought stress also decreases photorespiration, nitrate reductase and protein synthesis (Dinh et al. 2016; Sopandie 2013). The decrease in physiological activities can be seen from the decrease in plant growth such as plant height, plant diameter, and also the number of leaf pairs. Omprakash et al. (2017) states that lack of water in mature plants will cause loss of crop yields.

The clones had an effect on plant growth. Clone BP 308 showed the best results compared to the other three clones when they were during weeks 0 to 12 after treatment. These results indicated that before drought treatment BP 308 showed a better growth rate than the three other clones. Therefore, in order to see the direct effect of drought treatment, a reduction was made between seedling growth when the seedlings were in weeks 12 and 0 after treatment. The results of growth showed that clone BP 409 had higher plants and more number of leaf pairs compared to the other three clones, whereas the plant diameter did not differ significantly among these four clones (Table 2). 
Table 2. Growth of four Robusta coffee clones at 12 week after first treatment

\begin{tabular}{|c|c|c|c|c|c|c|c|}
\hline \multirow{2}{*}{ Clone } & \multicolumn{7}{|c|}{ Age of seedling (week after first drought treatmen) } \\
\hline & 0 & 2 & 4 & 6 & 8 & 10 & 12 \\
\hline & \multicolumn{7}{|c|}{----------- Seedlings height $(\mathrm{cm})$----------- } \\
\hline BP 308 & $15.65 \mathrm{a}$ & $\begin{array}{c}17.28 \mathrm{a} \\
(1.63)\end{array}$ & $\begin{array}{l}18.72 \mathrm{a} \\
(3.07 \mathrm{a})\end{array}$ & $\begin{array}{l}20.57 \mathrm{a} \\
(4.92 \mathrm{a})\end{array}$ & $\begin{array}{l}22.18 \mathrm{a} \\
(6.53 \mathrm{~b})\end{array}$ & $\begin{array}{l}23.11 \mathrm{a} \\
(7.46 \mathrm{~b})\end{array}$ & $\begin{array}{l}24.79 \mathrm{a} \\
(9.14 \mathrm{c})\end{array}$ \\
\hline BP 358 & $12.77 \mathrm{~b}$ & $\begin{array}{l}4.01 \mathrm{~b} \\
(1.24)\end{array}$ & $\begin{array}{c}15.29 \mathrm{~b} \\
(2.52 \mathrm{ab})\end{array}$ & $\begin{array}{l}16.90 \mathrm{~b} \\
(4.13 \mathrm{~b})\end{array}$ & $\begin{array}{l}18.71 \mathrm{~b} \\
(5.94 \mathrm{~b})\end{array}$ & $\begin{array}{l}19.41 \mathrm{~b} \\
(6.64 \mathrm{~b})\end{array}$ & $\begin{array}{l}21.45 \mathrm{c} \\
(8.68 \mathrm{c})\end{array}$ \\
\hline BP 409 & $11.66 \mathrm{bc}$ & $\begin{array}{c}12.86 \mathrm{~b} \\
(1.20)\end{array}$ & $\begin{array}{l}14.28 \mathrm{bc} \\
(2.62 \mathrm{ab})\end{array}$ & $\begin{array}{l}16.58 \mathrm{~b} \\
(4.92 \mathrm{a})\end{array}$ & $\begin{array}{l}18.97 \mathrm{~b} \\
(7.31 \mathrm{a})\end{array}$ & $\begin{array}{l}20.30 \mathrm{~b} \\
(8.64 \mathrm{a})\end{array}$ & $\begin{array}{c}23.07 \mathrm{~b} \\
(14.41 \mathrm{a})\end{array}$ \\
\hline BP 939 & $\begin{array}{c}11.38 \mathrm{c} \\
(1.28)\end{array}$ & $12.66 \mathrm{~b}$ & $\begin{array}{l}13.76 \mathrm{c} \\
(2.38 \mathrm{~b})\end{array}$ & $\begin{array}{c}15.80 \mathrm{~b} \\
(4.42 \mathrm{ab})\end{array}$ & $\begin{array}{l}17.84 \mathrm{~b} \\
(6.46 \mathrm{~b})\end{array}$ & $\begin{array}{l}18.92 \mathrm{~b} \\
(7.54 \mathrm{~b})\end{array}$ & $\begin{array}{l}21.64 \mathrm{bc} \\
(10.26 \mathrm{~b})\end{array}$ \\
\hline \multirow[t]{2}{*}{ F test } & $* *$ & $\begin{array}{c}* * \\
(\mathrm{~ns})\end{array}$ & $\begin{array}{l}* * \\
(*)\end{array}$ & $\begin{array}{c}* * \\
(* *)\end{array}$ & $\begin{array}{l}* * \\
(* *)\end{array}$ & $\begin{array}{c}* * \\
(* *)\end{array}$ & $\begin{array}{c}* * \\
(* *)\end{array}$ \\
\hline & \multicolumn{7}{|c|}{----------- Stem diameter (mm) ----------- } \\
\hline BP 308 & $2.68 \mathrm{a}$ & $\begin{array}{l}3.19 \mathrm{a} \\
(0.51)\end{array}$ & $\begin{array}{l}3.49 \mathrm{a} \\
(0.81)\end{array}$ & $\begin{array}{l}3.60 \mathrm{a} \\
(0.92)\end{array}$ & $\begin{array}{l}3.66 \mathrm{a} \\
(0.98)\end{array}$ & $\begin{array}{r}3.76 \mathrm{a} \\
(1.08)\end{array}$ & $\begin{array}{r}4.02 \mathrm{a} \\
(1.34)\end{array}$ \\
\hline BP 358 & $2.44 \mathrm{~b}$ & $\begin{array}{l}2.96 \mathrm{~b} \\
(0.52)\end{array}$ & $\begin{array}{c}3.32 \mathrm{ab} \\
(0.88)\end{array}$ & $\begin{array}{c}3.47 \mathrm{ab} \\
(1.03)\end{array}$ & $\begin{array}{c}3.53 \mathrm{ab} \\
(1.09)\end{array}$ & $\begin{array}{c}3.61 \mathrm{ab} \\
(1.17)\end{array}$ & $\begin{array}{c}3.87 \mathrm{ab} \\
(1.43)\end{array}$ \\
\hline BP 409 & $2.24 \mathrm{~b}$ & $\begin{array}{l}2.74 \mathrm{c} \\
(0.50)\end{array}$ & $\begin{array}{l}3.14 \mathrm{c} \\
(0.90)\end{array}$ & $\begin{array}{l}3.24 \mathrm{c} \\
(1.00)\end{array}$ & $\begin{array}{l}3.30 \mathrm{c} \\
(1.06)\end{array}$ & $\begin{array}{l}3.40 \mathrm{c} \\
(1.16)\end{array}$ & $\begin{array}{l}3.64 \mathrm{c} \\
(1.40)\end{array}$ \\
\hline BP 939 & $2.37 \mathrm{~b}$ & $\begin{array}{c}2.87 \mathrm{bc} \\
(0.50)\end{array}$ & $\begin{array}{c}3.25 \mathrm{bc} \\
(0.88)\end{array}$ & $\begin{array}{c}3.38 \mathrm{bc} \\
(1.01)\end{array}$ & $\begin{array}{c}3.45 \mathrm{bc} \\
(1.08)\end{array}$ & $\begin{array}{c}3.54 \mathrm{bc} \\
(1.17)\end{array}$ & $\begin{array}{c}3.80 \mathrm{bc} \\
(1.43)\end{array}$ \\
\hline \multirow[t]{2}{*}{ F test } & $* *$ & $\begin{array}{c}* * \\
(\mathrm{~ns})\end{array}$ & $\begin{array}{l}* * \\
(\mathrm{~ns})\end{array}$ & $\begin{array}{l}* * \\
(\mathrm{~ns})\end{array}$ & $\begin{array}{l}* * \\
(\mathrm{~ns})\end{array}$ & $\begin{array}{l}* * \\
(\mathrm{~ns})\end{array}$ & $\begin{array}{l}* * \\
(\mathrm{~ns})\end{array}$ \\
\hline & \multicolumn{7}{|c|}{------------ Number of leaf pairs ------------ } \\
\hline BP 308 & $4.33 \mathrm{a}$ & $\begin{array}{l}5.24 \mathrm{a} \\
(0.91)\end{array}$ & $\begin{array}{c}5.79 \mathrm{a} \\
(1.46 \mathrm{ab})\end{array}$ & $\begin{array}{c}6.14 \mathrm{a} \\
(1.81 \mathrm{ab})\end{array}$ & $\begin{array}{c}6.17 \mathrm{a} \\
(1.84 \mathrm{~b})\end{array}$ & $\begin{array}{c}6.57 \\
(2.24 \mathrm{ab})\end{array}$ & $\begin{array}{c}7.02 \\
(2.69 b)\end{array}$ \\
\hline BP 358 & $4.23 \mathrm{a}$ & $\begin{array}{l}5.08 \mathrm{a} \\
(0.85)\end{array}$ & $\begin{array}{l}5.60 \mathrm{ab} \\
(1.37 \mathrm{~b})\end{array}$ & $\begin{array}{l}5.98 \mathrm{ab} \\
(1.75 \mathrm{~b})\end{array}$ & $\begin{array}{l}5.97 \mathrm{ab} \\
(1.74 \mathrm{~b})\end{array}$ & $\begin{array}{c}6.57 \\
(2.34 \mathrm{a})\end{array}$ & $\begin{array}{c}6.88 \\
(2.65 \mathrm{~b})\end{array}$ \\
\hline BP 409 & $3.51 \mathrm{~b}$ & $\begin{array}{l}4.29 b \\
(0.78)\end{array}$ & $\begin{array}{c}5.33 b \\
(1.82 a)\end{array}$ & $\begin{array}{l}5.71 b c \\
(2.20 a)\end{array}$ & $\begin{array}{l}5.73 b c \\
(2.22 a)\end{array}$ & $\begin{array}{c}6.19 \\
(2.68 a)\end{array}$ & $\begin{array}{c}7.01 \\
(3.50 \mathrm{a})\end{array}$ \\
\hline BP 939 & $4.19 \mathrm{a}$ & $\begin{array}{l}4.86 \mathrm{a} \\
(0.67)\end{array}$ & $\begin{array}{l}5.29 \mathrm{~b} \\
(1.10 \mathrm{~b})\end{array}$ & $\begin{array}{l}5.49 \mathrm{c} \\
(1.30 \mathrm{c})\end{array}$ & $\begin{array}{l}5.53 \mathrm{c} \\
(1.34 \mathrm{c})\end{array}$ & $\begin{array}{c}6.03 \\
(1.84 \mathrm{~b})\end{array}$ & $\begin{array}{c}6.44 \\
(2.25 \mathrm{~b})\end{array}$ \\
\hline$F$ test & $* *$ & $\begin{array}{c}* * \\
(\mathrm{~ns})\end{array}$ & $\begin{array}{l}* * \\
(*)\end{array}$ & $\begin{array}{c}* * \\
(* *)\end{array}$ & $\begin{array}{c}* * \\
(* *)\end{array}$ & $\begin{array}{c}\mathrm{ns} \\
(* *)\end{array}$ & $\begin{array}{c}\mathrm{ns} \\
(* *)\end{array}$ \\
\hline
\end{tabular}

Drought had a significant effect on wet weight, dry weight and root length. The response patterns formed followed the linear regression equations while the root volume variable, the drought factor showed nonsignificantly different effect. The wet weight of the seeds got increased with the addition of water volume to 2.5 Eo. The equation formed from the results of this regression analysis is $\mathrm{y}=4.0049 \mathrm{x}+11,975$. Dry weight also showed a similar response pattern to that of wet weight. The results of the regression equation formed from the dry weight variable due to differences in drought levels follow this equation: $y=1.2653 x+4.2183$. Root length also got increased due to an increase in water volume levels. The equation formed from the results of this regression analysis is $\mathrm{y}=1.535 \mathrm{x}+20.318$ (Table 3 ).

The results showed that clones had a significant effect on the variables of wet weight, dry weight and root volume. Clone 308 had higher values on wet weight, dry weight and root volume compared to the other three clones. The variables of wet weight, dry weight, and root volume were 
The growth response of seedlings of four Robusta coffee (Coffea canephora pierre. Ex. A. Froehner) clones to dought stress

Table 3. Biomass and rooting of coffee seedlings in several drought levels at 12 week after first treatment

\begin{tabular}{|c|c|c|c|c|}
\hline Drought level, Eo & Wet weight, g & Dry weight, $\mathrm{g}$ & Root length, $\mathrm{cm}$ & Root volume, $\mathrm{mL}$ \\
\hline 0.5 & $15.31 \mathrm{~b}$ & $5.01 \mathrm{~b}$ & $22.10 \mathrm{~b}$ & 4.96 \\
\hline 1.0 & $15.21 \mathrm{~b}$ & $5.51 \mathrm{~b}$ & $21.23 \mathrm{~b}$ & 5.35 \\
\hline 1.5 & $15.96 \mathrm{~b}$ & $5.53 \mathrm{~b}$ & $21.71 \mathrm{~b}$ & 4.47 \\
\hline 2.0 & $21.06 \mathrm{a}$ & $7.22 \mathrm{a}$ & $23.02 \mathrm{ab}$ & 5.45 \\
\hline 2.5 (control) & $22.39 \mathrm{a}$ & $7.32 \mathrm{a}$ & $25.05 \mathrm{a}$ & 6.00 \\
\hline $\mathrm{F}$ test & $* *$ & $* *$ & * & ns \\
\hline Response & $\mathrm{L} * *$ & $\mathrm{~L}^{* *}$ & $\mathrm{~L}^{* *}$ & ns \\
\hline
\end{tabular}

Table 4. Total Biomass and sedling roots four Robusta coffee clone at 12 week after the first treatment

\begin{tabular}{lcccc}
\hline Clone & Wet weight, $\mathrm{g}$ & Dry weight, $\mathrm{g}$ & Root length, cm & Root volume, mL \\
\hline BP 308 & $21.80 \mathrm{a}$ & $7.39 \mathrm{a}$ & 22.00 & $6.78 \mathrm{a}$ \\
BP 358 & $17.35 \mathrm{~b}$ & $6.04 \mathrm{~b}$ & 22.49 & $5.69 \mathrm{ab}$ \\
BP 409 & $15.37 \mathrm{~b}$ & $5.35 \mathrm{~b}$ & 22.06 & $3.84 \mathrm{c}$ \\
BP 939 & $17.41 \mathrm{~b}$ & $5.69 \mathrm{~b}$ & 23.92 & $4.69 \mathrm{bc}$ \\
F test & $* *$ & $* *$ & $\mathrm{~ns}$ & $* *$ \\
\hline Note: & The numbers followed by the same letters in the same colums show no significant using DMRT $\alpha 5 \%$.
\end{tabular}

destructive observations, thus no initial data were obtained when in week 0 after treatment. Better results of root biomass and clone BP 308 volume were accumulated of growth increment from the beginning of the cuttings until the end of the drought period or 7 months after planting (Table 4).

This result is in accordance with the research by Silva et al. (2013) that found that sufficient irrigation (field capacity) on Robusta coffee seedlings that can lead clones with high ability to use water show increased biomass, whilst when water condition is $66 \%$ of field capacity, there is a delay in the increase in biomass due to the use of water that was more conservative. The same thing happens to Arabica coffee seeds that experience Drought stress. The stress cause damage to the seeds. Damage that occurs has a correlation with the time of drought stress. In these conditions, Arabica coffee seedlings decrease biomass above and in the soil (Chen et al., 2015). Deeper root systems of tolerant drought stress clones make it possible to get greater access to water at the bottom and to maintain more favorable internal water status than drought-sensitive clones (Pinheiro et al., 2005).

\section{Leaf Anatomy}

The results also showed that drought had a significant effect on leaf thickness, palisade tissue thickness, and stomatal density. Leaf thickness showed the quadratic response pattern due to drought treatment, meaning that there was a maximum point due to the treatment. The quadratic equation formed for the leaf thickness variable is $\mathrm{y}=-7.1261 \mathrm{x} 2$ $+24.217 \mathrm{x}+140.22$ with maximum point in water volume of $1.7 \mathrm{Eo}$, while the variables of palisade tissue thickness and stomatal density showed a linear regression pattern (Table 5).

Table 5. Stomatal density four Robusta coffee clone at 12 week after the first treatment

\begin{tabular}{lc}
\hline Drought level, Eo & Stomata density, $\mathrm{mm}^{-2}$ \\
\hline 0.5 & 78.70 \\
1.0 & 73.32 \\
1.5 & 70.77 \\
2.0 & 63.41 \\
2.5 (control) & 68.08 \\
F test & $\mathrm{ns}$ \\
Response & $\mathrm{L}^{*}$ \\
\hline Note: $\quad$ F test used DMRT; * significant $\alpha 5 \%$; $^{* *}$ significant \\
\multicolumn{2}{c}{$\alpha 1 \% ;$ ns non significant $\alpha 5 \% ;$ Response used } \\
\multicolumn{2}{c}{ regresion test; L showed linear regresion. }
\end{tabular}

Besides, the clones affected the leaf thickness and the palisade tissue thickness but did not significantly affect the wax layer 
thickness and stomatal density. BP 409 had thinner leaves compared to that of other 3 clones. The thickest palisade tissues were found in clones BP308 and BP409, whereas BP 358 and BP 939 had the same palisade tissue thickness (Table 6).

Table 6. Stomata density of four Robusta clones at 12 weeks after first treatment

\begin{tabular}{lc}
\hline Clone & Stomata density $\left(\mathrm{mm}^{-2}\right)$ \\
\hline BP 308 & 72.02 \\
BP 358 & 75.87 \\
BP 409 & 73.83 \\
BP 939 & 61.71 \\
Uji F & $n s$ \\
\hline Note: & The numbers followed by the same letters in the \\
& same colums show no significant using DMRT $\alpha$ 5\%.
\end{tabular}

The interaction between drought and clones had a significant effect on leaf thickness, wax layer thickness and palisade tissue thickness. In drought of $0.5 \mathrm{Eo}$, the clones that had the thickest leaf was BP 939, followed by BP 308, BP 358, and BP 409. BP 939 responded to water deficit by thickening the leaves. BP 409 showed its thickest wax layer and palisade tissue in drought of 0.5 Eo. BP 409 responded to water deficit by thickening the wax layer and palisade tissue (Table 7).

These research results are in line with that of Omprakash et al. (2017) which reveal that the plants which are tolerant to drought conducted a thorough change in the plant tissue, physiology and molecular level. The combination of these changes determines the ability of plants to withstand limited water conditions. Modifications made by tolerant plants include forming thicker parts of the leaves. The thicker leaves will store more water; the leaves will be narrower to reduce evaporation. In this research, it is identified that the tolerance mechanism of BP 939 to drought stress was by thickening the leaves when under drought condition of 0.5 Eo. Such modifications of leaf anatomy as thickening the mesophyll and epidermis and increasing stomatal density are functioned as a mechanism of adaptation to drought stress (Grisi, 2008; Melo et al., 2014).

Wax layer is the outermost layer of the leaf which serves to protect the parts inside and to prevent water loss. Thicker wax layer is more effective at protecting plant parts inside and reducing water loss to the environment through leaves. In the wax layer there is a metabolism of plants in preventing water loss from leaves to the environment, but this still needs to be investigated further (Jetter \& Riederer, 2016). BP 409 responded to water deficit by thickening the wax layer to reduce water loss from plant tissue.

Table 7. Interaction between the level of drought and clones on leaf anatomy at 12 weeks after first treatment

\begin{tabular}{|c|c|c|c|c|c|}
\hline \multirow{2}{*}{ Clone } & \multicolumn{5}{|c|}{ Volume of watering (Eo) } \\
\hline & 0.5 & 1.0 & 1.5 & 2.0 & 2.5 \\
\hline & \multicolumn{5}{|c|}{----------- Leaf thickness $(\mu \mathrm{m})$---------- } \\
\hline BP308 & $154.33 \mathrm{ab}$ & $170.67 \mathrm{a}$ & $160.67 \mathrm{~b}$ & $160.33 \mathrm{ab}$ & $158.33 \mathrm{~b}$ \\
\hline BP358 & $149.33 b$ & $148.67 b$ & $170.00 \mathrm{ab}$ & $168.33 \mathrm{a}$ & $169.33 \mathrm{a}$ \\
\hline BP409 & $136.00 \mathrm{c}$ & $148.00 \mathrm{~b}$ & $147.67 \mathrm{c}$ & $150.00 \mathrm{~b}$ & $155.00 \mathrm{~b} \mathrm{c}$ \\
\hline \multirow[t]{2}{*}{ ВР939 } & $162.00 \mathrm{a}$ & $161.00 \mathrm{a}$ & $172.34 \mathrm{a}$ & $151.33 \mathrm{~b}$ & $146.00 \mathrm{c}$ \\
\hline & \multicolumn{5}{|c|}{---------- Wax layer thickness $(\mu \mathrm{m})$---------- } \\
\hline BP308 & $4.00 \mathrm{~b}$ & $4.33 \mathrm{a}$ & $4.33 \mathrm{a}$ & $4.33 \mathrm{ab}$ & $4.67 \mathrm{a}$ \\
\hline BP358 & $4.00 \mathrm{~b}$ & $4.00 \mathrm{a}$ & $4.00 \mathrm{a}$ & $5.00 \mathrm{a}$ & $4.67 \mathrm{a}$ \\
\hline BP409 & $5.67 \mathrm{a}$ & $4.67 \mathrm{a}$ & $4.67 \mathrm{a}$ & $4.00 \mathrm{~b}$ & $4.33 \mathrm{a}$ \\
\hline \multirow[t]{2}{*}{ ВР939 } & $4.33 \mathrm{~b}$ & $4.67 \mathrm{a}$ & $4.33 \mathrm{a}$ & $5.00 \mathrm{a}$ & $4.00 \mathrm{a}$ \\
\hline & \multicolumn{5}{|c|}{----------- Palisade tissue thickness $(\mu \mathrm{m})$----------- } \\
\hline BP308 & $31.34 \mathrm{a}$ & $31.02 \mathrm{a}$ & $30.48 \mathrm{a}$ & $27.62 \mathrm{a}$ & $34.28 \mathrm{a}$ \\
\hline BP358 & $20.22 \mathrm{c}$ & $25.41 \mathrm{~b}$ & $28.92 \mathrm{a}$ & $29.56 \mathrm{a}$ & $29.30 \mathrm{~b}$ \\
\hline BP409 & $28.71 \mathrm{a}$ & $28.71 \mathrm{ab}$ & $29.70 \mathrm{a}$ & $28.49 \mathrm{a}$ & $34.83 \mathrm{a}$ \\
\hline ВР939 & $24.41 \mathrm{~b}$ & $24.91 \mathrm{~b}$ & $29.06 \mathrm{a}$ & $30.69 \mathrm{a}$ & $31.34 \mathrm{ab}$ \\
\hline
\end{tabular}


In addition, thicker palisade tissue is useful for plants for better vegetative growth because palisade tissue is the location of chlorophyll which functions to capture solar energy that plays an important role in photosynthesis. Thicker palisade tissue allows plants to have a higher amount of chlorophyll in order to optimize photosynthesis process. In seeds or plants which have not produced, the results of photosynthesis in the form of glucose or carbohydrates will be distributed throughout the plant through vascular tissue and be used for vegetative growth of plant. In this research, BP 409 responded to water deficit by thickening palisade tissue. Thick palisade tissue is positively correlated with plant height and total dry weight (Table 9).

\section{Stress Sensitivity Index}

The results show that the clones BP 409 and BP 939 had lower stress sensitivity index values compared with clones BP 308 and BP 358. The lower the values of stress sensitivity index, the higher is the drought stress tolerance of seedlings. The variables used to measure the stress sensitivity index in this research is the plant height variable because this is one of the indicators used for seeds ready to be distributed (Table 8).
Table 8. Stress sensitivity index of four Robusta clones three months after the first treatment

\begin{tabular}{lcc}
\hline Clone & Stress sensitivity index & Stress tolerance \\
\hline BP 308 & $0.70 \mathrm{a}$ & Moderate \\
BP 358 & $0.68 \mathrm{a}$ & Moderate \\
BP 409 & $0.37 \mathrm{~b}$ & Tolerant \\
BP 939 & $0.47 \mathrm{~b}$ & Tolerant \\
F test & & \\
\hline Note: & The number followedby the same letters in the same \\
& column shown no significant using DMRT $\alpha 5 \%$.
\end{tabular}

\section{Correlation among Variables}

The results showed that there was a correlation among the variables of growth, biomass, roots and leaf anatomy. Seed height correlated with the number of leaf pairs, root length, palisade and tissue stomatal density with the correlation coefficient of $0.33,0.27$, $0.31,046$ and -0.26 respectively. Positive correlation values indicate that these variables have a linear growth while negative correlation value indicates that the variables correlated have opposite growth values. For example, the seed height variable was negatively correlated with stomatal density, meaning that higher seedling height was associated with lower stomata. Correlation coefficient describes the level of relationship between two correlated variables, and it ranges from 0 to 1 . In other words, the higher the correlation coefficient, the stronger is the relationship. There were other variables that correlated

Table 9. Correlation between growth variables, biomass, root length, and leaf anatomy at three months after first treatment

\begin{tabular}{|c|c|c|c|c|c|c|c|c|}
\hline & $\mathrm{SH}$ & SD & NLP & RL & RV & TDW & $\mathrm{LT}$ & WLT \\
\hline Seedlings height & 1.00 & & & & & & & \\
\hline Stem diameter & -0.02 & 1.00 & & & & & & \\
\hline Number of leaf pairs & $0.33^{* *}$ & -0.15 & 1.00 & & & & & \\
\hline Root length & $0.27^{*}$ & 0.07 & 0.11 & 1.00 & & & & \\
\hline Root volume & -0.08 & 0.00 & 0.16 & 0.10 & 1.00 & & & \\
\hline Total dry weight & $0.31^{*}$ & 0.01 & 0.08 & $0.3^{*}$ & $0.63^{* *}$ & 1.00 & & \\
\hline Leaf thickness & 0.09 & -0.01 & -0.13 & 0.05 & 0.24 & 0.22 & 1.00 & \\
\hline Wax layer thickness & 0.14 & -0.25 & 0.16 & -0.02 & -0.02 & 0.01 & -0.23 & 1.00 \\
\hline Palisade tissue thickness & $0.46^{* *}$ & -0.17 & 0.14 & 0.13 & 0.02 & $0.29^{*}$ & 0.12 & 0.15 \\
\hline
\end{tabular}


with each other in this research. First, root length was positively correlated with total dry weight with the correlation coefficient of 0.3 and negatively correlated with stomatal density with the correlation coefficient of 0.37 . Second, root volume was positively correlated with total dry weight with the correlation coefficient of 0.63 . Total dry weight was also positively correlated with palisade tissue thickness with the correlation coefficient of 0.29 (Table 9).

Seedling height and total dry weight of plants are important growth variables for determining tolerance of plants to drought stress. In this research, it can be seen that root length and thickness of palisade tissue can be a determinant of plant height that can be reached. The drought treatment of 0.5 Eo was a treatment that caused the Robusta coffee seedlings under severe drought stress conditions, identified from the lower growth of Robusta coffee seeds compared with other treatments. Maintaining the status of water remains high in the tissues is one mechanism of plants to survive in drought stress.

\section{CONCLUSIONS}

Reduction in the volume of watering from 2.5 Eo until 0.5 Eo causes drought, reduce coffee growth linearly. Clone BP 409 and BP 939 had better tolerance of drought stress compared with BP 308 and BP 358. The anatomical adaptation of leaves of BP 409 to drought stress was by thickening of wax layer and palisade tissue. BP 939 thickened its leaves due to drought stress as a mechanism of adaptation to such condition.

\section{ACKNOWLEDGEMENTS}

Our sincere gratitude goes first to the LPDP (the Indonesian education fund management institution) as the sponsor of research funding, and second to the Indonesian Coffee and Cocoa
Research Institute for facilitating this research. Additionally, we would like to thank Mr. Ucu Sumirat and his research team as well as the research team at the Laboratory of Agronomy in the Indonesian Coffee and Cocoa Research Institute who have contributed to giving advice and power to this research.

\section{REFERENCES}

Abdoellah, S. (1997). Ancaman cekaman kekeringan di musim kemarau panjang pada tanaman kopi dan kakao. Warta Puslit. Kopi dan Kakao, 13,77-82.

Achar, D.; G. Daniel; M.G. Awati; D. Venkataramanan; M. Udayakumar \& T.G. Prasad (2011). Study of genetic variability of root and other associated physiological traits in Coffea canephora. Journal Coffee Research, 39, 33-54.

Anim-Kwapong E;; G.J. Anim-kwapong \& B. Adomako (2011). Variation and association among characters genetically related to yield and yield stability in Coffea canephora genotypes. Journal Plant Breeding Crop Science, 3, 11-20.

Anim-Kwapong, E. \& B. Adomako (2010). Genetic and environmental correlation between bean yield and agronomic traits in Coffea canephora. Journal Plant Breeding Crop Science, 2, 64-72.

Chemura, A.; C. Mahoya; P. Chidoko \& D. Kutywayo (2014). Effect of soil moisture deficit stress on biomass accumulation of four coffee (Coffea arabica) Varieties in Zimbabwe. ISRN Agronomy, 2014, 1-10.

Chen, K.; J. Liu; L. Xu; J. Wang; Y. Liu \& J. Luo (2015). Responses of Coffea arabica L. seedlings during drought stress. Southwest China Journal of Agricultural Science, 28, 24-28.

Dinh, S.N.; T.Z.T. Sai; G. Nawaz; K. Lee \& H. Kang (2016). Abiotic stresses affect differently the intron splicing and expression of chloroplast genes in coffee plants (Coffea arabica) and rice (Oryza sativa). Journal of Plant Physiologycal, 201, 85-94. 
Dominghetti, A.W.; A.D.J. Souza; H.D.O. Silveira; J.D.V. Sant' Ana; K.R.D. de Souza; R.J. Guimarães \& J.R. Lacerda (2016). Tolerance to drought of coffee trees produced by cuttings and somatic embryogenesis. Coffee Science, 11, 117-126.

Farooq, M.; A. Wahid; N. Kobayashi; D. Fujita \& S.M.A. Basra (2009). Plant drought stress: effects, mechanisms and management. Agronomy Sustainability, 29, 185-212.

Gardner, F.P.; R.B. Pearce \& R.L. Mitchell (1985). Physiology of Crop Plants. The Iowa University Press. United States.

Goldesworthy, P.R. \& N.M. Fisher (1996). Fisiologi Tanaman Budidaya Tropika. UGM Press. Yogyakarta.

Grisi, F.A. (2008). Avaliações foliares em mudas de café 'Catucaí' e 'Siriema' submetidas ao estresse hídrico. Ciência e Agrotecnologia, 32, 1730-1736.

Jetter, R. \& M. Riederer (2016). Localization of the transpiration barrier in the epidermis and intracuticular waxes of eight plant species: Water transport resistances are associated with fatty acyl rather than alicyclic components. Plant Physiology, 170, 921-934

King'oro, M.W.; D. Mushimiyamana; J.J. Cheserek \& B.M. Gichimu (2014). Effect of different watering regimes on agro-morphology of selected coffee genotypes. American Journal of Experimental Agriculture, 4, 1016-1026.

Melo, E.F.; C.N. Fernandes-Brum; F.J. Pereira; E.M.D. Castro \& A. Chalfun-Júnior (2014). Anatomic and physiological modifications in seedlings of Coffea arabica cultivar Siriema under drought conditions. Ciência e Agrotecnologia, 38, 25-33.

Mohammed, M.; E. Meskelu \& T. Shimbir (2018). Droughtand Watershed Management. Ethiopian Institute of Agricultural Research (EIAR). Addis Abeba.

Nur, A.M. (1992). Adaptasi beberapa klon kopi Robusta terhadap tekanan kekeringan. Pelita Perkebunan, 8, 55-60.
Omprakash; R. Gobu; P. Bisen; M. Baghel \& K.N. Chourasia (2017). Resistance/Tolerance mechanism under water deficit (drought) condition in plants. Internatinal Journal Current Microbiology Applied Science, 6, 66-78.

Pinheiro, H.A.; F.M. DaMatta; R.M.C. Agnaldo; E.L. Marcelo \& D. Carlos (2005). Drought tolerance is associated with rooting depth and stomatal control of water use in clones of Coffea canephora. Annals of Botany, 96, 101-108.

Pusat Penelitian Kopi dan Kakao Indonesia (2006). Pedoman Teknis Budidaya Tanaman Kopi. Pusat Penelitian Kopi dan Kakao Indonesia. Jember.

Salisbury, B.F. \& W.C. Ross (1995). Fisiologi Tumbuhan Jilid 3 (terjemahan). Institut Teknologi Bandung. Bandung.

Silva, P.E.M.; P.C. Cavatte; L.E. Morais; E.F. Medina \& F.M. DaMatta (2013). The functional divergence of biomass partitioning, carbon gain and water use in Coffea canephora in response to the water supply: Implications for breeding aimed at improving drought tolerance. Environmental dan Experimental Botany., 87, 49-57.

Sopandie, D. (2013). Fisiologi Adaptasi Tanaman Terhadap Cekaman Abiotik pada Agroekosistem Tropika. IPB Press. Bogor.

Sulistyono, E. \& A.E. Juliana (2014). Drought volume based on pan evaporation and their effeects on water use efficiency and yield of hidroponically grown chilli. Journal of Tropical Crop Science, 1, 9-12.

Sulistyono, E. \& H. Riyanti (2015). Volume irigasi untuk budidaya hidroponik melon dan pengaruhnya terhadap pertumbuhan dan produksi. Jornal Agronomy Indonesia, 43, 213-218.

Tesfaye, S.G.; M.R. Ismail; M.F. Ramlan; M. Marziah; H. Kausar \& M.A. Hakim (2015). Effect of water deficiency on growth and dry matter yield of selected in Robusta coffee (Coffea canephora) clones in Malaysia. Journal of Environmental Biology, 36, 1239-1245.

$$
* * 0 * *
$$

